\title{
RURAL-TO-URBAN MIGRATION OF YOUNG PEOPLE AND ITS EFFECT ON SMALL CITIES IN HUNGARY
}

\author{
Harshavardhan Reddy KUMMITHA ${ }^{\text {a }}$, Nikoletta TÓTH-KASZÁS ${ }^{\text {, }}$, Krisztina \\ KELLER $^{c}$, Zoltán BIRKNER ${ }^{d}$
}

\begin{abstract}
aBudapest Business School, Faculty of Commerce, Hospitality and Tourism, 9-11. Alkotmány Street, H1054 Budapest, Hungary; Email: kummitha.harshavardhan@uni-bge.hu

b,dUniversity of Pannonia, Applied Management Institute, Nagykanizsa Campus, H-8800 Nagykanizsa, 18. Zrínyi street, Hungary; Email: kaszas.nikoletta@uni-pen.hu, birkner.zoltan@uni-pen.hu ${ }^{c}$ Corvinus University of Budapest, Institute of Marketing, Department of Tourism, H-1093 Budapest, 8. Fővám square, Hungary, Email: krisztina.keller@uni-corvinus.hu
\end{abstract}

Cite this article: Kummitha, H. R., Tóth-Kaszás, N., Keller, K., Birkner, Z. (2020). Rural-to-Urban Migration of Young People and its Effect on Small Cities in Hungary. Deturope. 12(2), 71-83

\begin{abstract}
Changes in rural Hungary have been increasing rapidly ever since the government passed the Local SelfGovernment Act in 1990. The policies set out in this Act affected the local funding systems in Hungary negatively, which led to a rural-to-urban migration in the country. This paper examines the youth's perception of urban migration in Hungary. Data has been collected via questionnaire-based surveys among students of six high schools of the city of Nagykanizsa in Hungary between January and October of 2018. A total of 1197 filled out forms were collected. This paper has a triple aim: to provide an analysis of the interests of youth in smaller towns seeking answers to what would make them stay in such towns and start their careers locally; to identify the factors that influence their inland rural-to-urban migration and to find out what strategies of rural community centers work best in keeping them home in small cities. Based on our findings, recommendations were drawn up in order to initiate the development of new projects in small cities which utilize the arguments and needs of the local youth discovered in the study area of our survey.
\end{abstract}

Keywords: Urbanization; Migration; Small Cities; Young Generation.

\section{INTRODUCTION}

The United Nations and the International Organization for Migration in 2015 both estimated that around 3 million people migrate to cities every week for livelihood purposes. Approximately $54 \%$ of people worldwide now live in cities, indicating that world urban population is increasing by almost 6 million people annually (Chittoor, 2018). According to the UN Global Migration Youth report (2014) young immigrants aged 15 to 24 comprised 12\% of the total migrant population. In 2015, there were 28.3 million international migrants aged between 15 and 25 in the world translating to one-eighth of the total of 232 million international migrants. (Global Migration and Youth Report 2016). Urbanization and globalization trends incite inland rural-to-urban migration in Hungary. Young Hungarians' perceptions of global 
trends and of modern way of life are described in detail in Malota's work (Malota, 2012). Gáti and Malota (2017) analyzed the aspects of educational tourism, when members of young generations travel to cities with favorable higher educational institutions, which tend to be large, urbanized cities.

Rural to urban migration in Hungary is partly influenced by employment and educational factors. It is estimated by the Hungarian statistics authority that urban population increases day by day and approximately $65 \%$ of the country's population lives in urban areas (KSH, 2017). It is also estimated that 7 out of 10 young people living in rural areas would prefer to move to urban areas (Sawyer et al., 2001). The primary motivation for rural-to-urban immigration is the lack of basic facilities in small cities, such as basic amenities and education and employment opportunities (Okhankhuele \& Opafunso, 2013). Urban development has progressed rapidly due to urbanization and globalization factors concerning economic development and improving infrastructure and social policies (Ramachandran, 2006; Kummitha, 2020). Besides migration, there is a tendency of commuting from small villages to nearby cities (Szőke \& Kovács, 2016). Commuters may live in rural areas, but their lives' focus is partially on the city they spend most of their day in. In this present migration scenario, we would like to analyze young people's perception about urban migration.

The Hungarian rural society suffers from substantial inequalities within the rural population, mostly of poor employment opportunities and of low income (Kovács, 2012; Kok, 1999). Hungarian rural population has been decreasing rapidly since the government passed the local government Act in 1990. In accordance with this Act, measures were taken to restructure the funding system to rural authority funding these authorities were suffering from declining financial viability in rural areas (Horvath, 2016). As a result, rural-to-urban migration in Hungary increased rapidly after this Act came into effect. This gradual increase, mainly due to globalization and urbanization, increased the number of employment opportunities in urban areas. Moreover, the government increased the supply of housing in the cities. The increased housing supply in major cities causes major migration from small cities to urban areas. At this juncture, Hungarian urban governance plays a vital role in formulating and implementing innovative policy with the aim of providing access to basic needs to attract people - particularly young people - from rural towns to urban localities. 


\section{RESEARCH AND THEORETICAL BACKGROUND}

Urbanization has accelerated in the past few decades in Hungary. In 1949, 37.5\% of the population lived in 50 towns around Hungary. In 1995, 65\% of Hungarians lived in 194 cities. In 2016, 71.67\% of the Hungarian population lived in cities. Because of the declining population, a process that has been ongoing since the early 1980s, Hungarian urban population increased gradually (Dövényi \& Kovács, 2006). From 1995 to 2016 only 75 cities have increased their population. About one third of the inland immigration moves to Budapest metropolitan areas (Ország \& Szobonya, 2013). Internal migration is defined as a movement of people in space, often involving a change in the usual place of residence; it is a movement within national boundaries (International Union for the Scientific Study of Population, 1982). The United Nation's Global Migration Database (UNGMD) shows that the largest share of people among migrants are those in their early twenties, and they choose to migrate due to educational purposes (Greenwood, 2001). Caldwell's article explains that "what education does, more than anything else, is to promote long-term rural-urban migration" (Caldwell, 1969). Young people migrate to urban areas for plenty of reasons, such as higher education, founding and starting of businesses or getting married.

There is now an emerging trend among migration scholars interested in understanding the emotional influencing factors of young people towards urban migration. The influencing push factors for migration are better financial and work opportunities, better education and better social life, and pull factors are lack of facilities and high unemployment rates in rural areas; these factors are mentioned in studies by (Miguel \& Hamory, 2009; Eckert et al., 2019; Dziewonski, 1992). According to the International Labor report, there were 71 million unemployed young people worldwide in 2016. This unemployment rate causes the young generation to migrate to urban regions in the hope of finding jobs. As we mentioned rural-tourban inland migration happened in several transitional stages in Hungary. The most effective phase was during the 1960's when Hungary became an industrialized country in East-Central Europe (Brown \& Schafft, 2002). Inland migration from small agricultural regions was directed towards industrialized cities, mainly to Budapest. This flow of intraregional migration continued until 1989. During 1990, internal migration slightly decreased due to economic and social changes in urban areas. According to (Günther, 2000; The international organization for migration, 2018) Hungarian internal migration happened in four phases. 
Phase 1 (From the beginning of 1990 to 1997): internal migration decreased until 1994, afterwards it started to stagnate followed by a slight increase due to the Hungarian local government act of 1990 .

Phase 2 (From the beginning of 1998 to 2004): Migration moving back to villages from Budapest began, with a peak of around 20000 people returning to villages due to the high living costs of the Budapest region.

Phase 3 (From 2005 to 2010): This period was a period of economic development. The migration rate increased again: negative immigration turned into positive as people started migrating to Budapest again in 2006. At the same time, villages suffered a population decline.

Final Phase / Phase 4 (From 2010 to 2018): In the period of the global financial crisis migration decreased. Below (Fig.1) indicating that from 2010 to 2013 migration to urban cities was stable. From 2014 to 2018 immigrant movement to cities saw a gradual increase. At present, the young generation is moving from small cities to Budapest for employment and educational purposes and they are not showing signs of planning to return to their hometowns.

Figure 1 Rural to Urban Inland immigration in Hungary

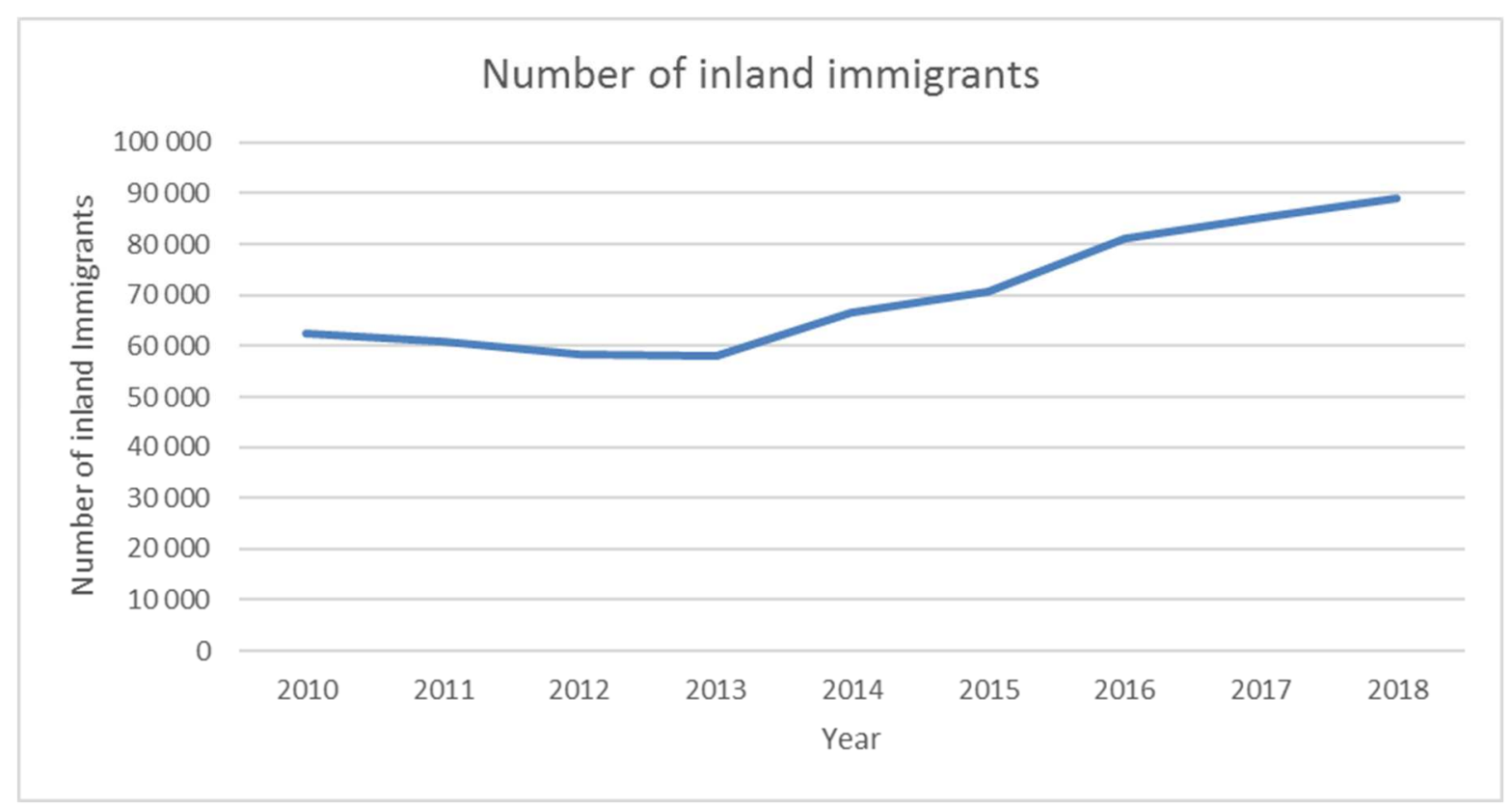

Source: KSH (2010-2018)

\section{DATA AND METHODS}

We have conducted our questionnaire-based survey among the students of the selected city's six high schools and one university between January and October of 2018. We have taken into 
consideration attitudinal and behavioral aspects (Gyulavári, 2013) during our research as well. The aim of our research was to understand the respondents' opinion of their town as well as their connection to the town and the extent of the city's role in their plans for the future.

We aimed to conduct a complete survey, meaning that we wanted to know the opinions of all students over the age of 14 who study in town, so no sampling method was chosen, the total base population was targeted with the query. At the year of the research (school year 2016/2017) the selected town had 2905 students; they were the base population. Students filled in our questionnaires during homeroom classes, mostly on paper forms, which were digitalized and analyzed later. Unfortunately, not all students were in schools on inquiry days because of illness and other reasons while others refused to answer. As a result, out of the available total base population of 2905 people, 1197 valid filled out forms were received in an estimable manner, resulting in a 41.2 per cent response rate.

The questionnaire primarily consisted of closed-ended questions, thus supporting quick completion and facilitating the quantitative assessment. Microsoft Excel and SPSS programs were used in the processing and analysis phase of the completed questionnaires. With the help of Excel primary frequencies were calculated and illustrations were prepared, while the utilization of SPSS was carried out in the context of the correlation investigations. Among the latter, due to the metric nature of the variables, crosstab analysis was used. The crosstab analysis is a statistical technique that describes two or more variables simultaneously with a table that shows the combined distribution of two or more categorized or value-dependent variables (Sajtos \& Mitev, 2007: 138). The relationship between the examined variables can be examined with the help of the Chi-square statistic method. If the significance level of the Chi-square is $<0.05$, the relationship can be assumed. Once the statistical significance has been demonstrated, we can also test the strength of the relationship, for which the Cramer-V is best suited, with values ranging from -1 to 1 , with values of 0 and close to no relationship, and an absolute value of 1 or close shows the closeness of the relationship (Sajtos\&Mitev, 2007: 143).Among the respondents, $46 \%$ were female and $54 \%$ were male. $50 \%$ of those surveyed were locals, $8 \%$ were residents of other cities and $42 \%$ of smaller towns. The other attributes are shown in the below figure 2 . 
Figure 2 Distribution of respondent regarding their age and school type

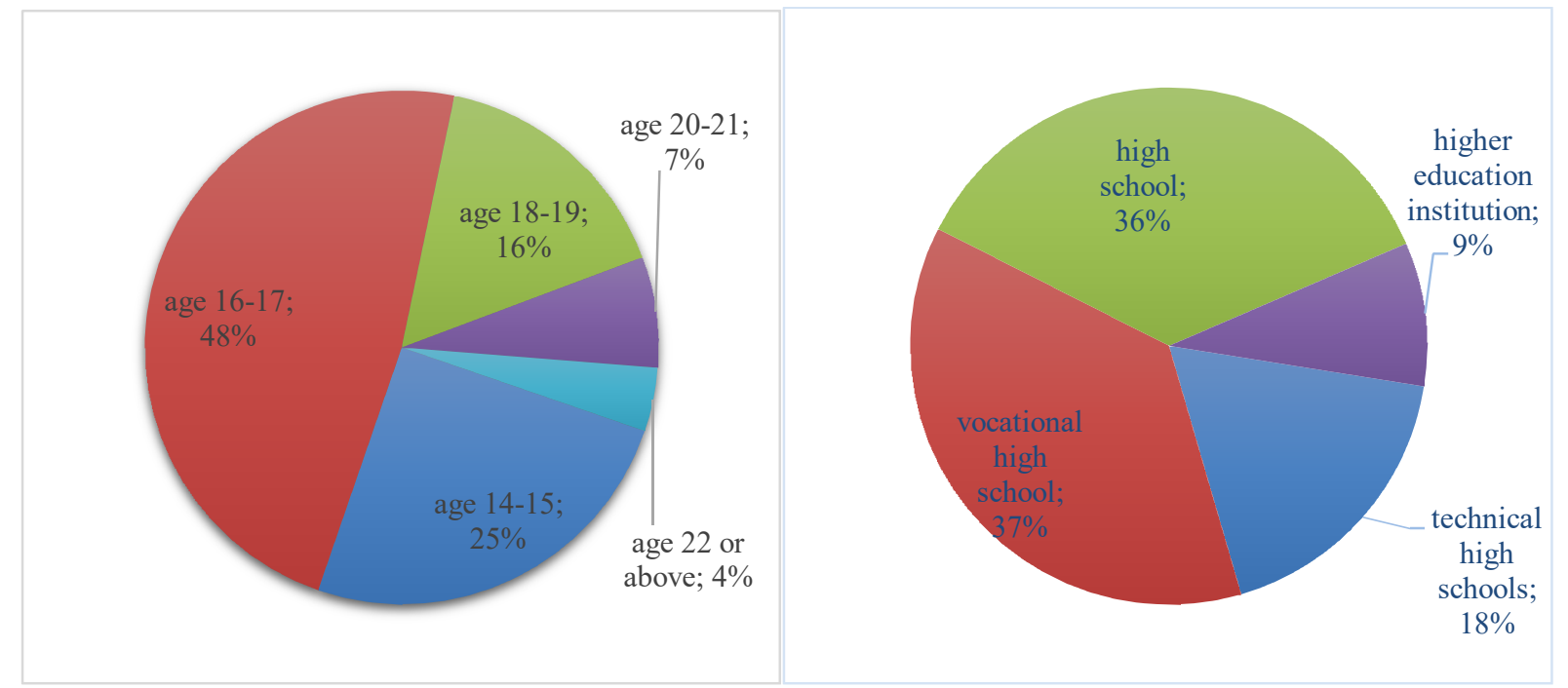

Source: own research, 2018

During our empirical research we have taken into consideration several viability issues, such as the development level of the local economy, standard of education and work, safety and cleanliness, traffic, entertainment and sport possibilities and other aspects in order to form our judgement of the city.

Regarding youth's desire to stay in their hometown we have formulated four questions in the questionnaire. These were focusing on planning to obtain professional qualification in the city; continuing the studies in a local higher-level education institution; knowing the employee opportunities in the town; planning to stay in the town after completing the studies.

\section{RESULTS}

In Table (1) the distribution rates of results measured on the four-point rating scale and the averages of the answers received are shown. All averages are above grade 2 and the share of negative valuations have not exceeded $16 \%$ in any of the answers given to the survey's questions. It can be observed that the renewed downtown area of the city had drawn the attention of youth to the highest extent - this renovation made the downtown a truly public place, complete with a pedestrian precinct and packed with restaurants and cafés.

It can also be observed that members of the $\mathrm{Z}$ generation (generation $\mathrm{Z}$ members were born after 1996) are satisfied with the creation of the ever so important opportunities for physical exercise for youth: they have many sports clubs, gyms and other cost-free ways to do sports in town. The education chapter scored high averages as well, however, it must be mentioned that 
the fact that the city is a university town had received the most " 1 " grades, indicating that such title doesn't mean much to members of the $\mathrm{Z}$ generation.

We can also see in the table that opportunities for student work and events dedicated to the youth have scored 2.55 and 2.53, respectively, which can be considered even more positive, but the share of those students who disagree or rather don't agree is on the rise. $15.1 \%$ of the surveyed youth believe city transportation leaves much to be desired (this chapter received the second most "1" grades), especially when traveling by vehicles is taken into consideration. Based on averages and in a descending order, the students consider the following areas those which need to be developed the most: cleanliness (2.49), public safety (2.48), high standard of living (2.47) and the level of economic development (2.43). Most of the $\mathrm{Z}$ generation students surveyed are not working yet, so in this regard, their value judgements are most likely based on the conditions provided by their parents. As seen in scientific literature, stable financial background is important to this generation, however, it is not the only factor that is taken into account when it comes to defining livable environment for them. Experiences and the importance of feeling good at a given place (standard of living) as well as being given the opportunity to work in jobs they enjoy (development level of local economy) are becoming much more important to them.

Table 1 Distribution of respondent opinion regarding the livability of the surveyed town

\begin{tabular}{|l|c|c|c|c|c|}
\hline Statements & $\begin{array}{l}\text { Strongly } \\
\text { disagree }\end{array}$ & Disagree & Agree & $\begin{array}{c}\text { Absolutely } \\
\text { agree }\end{array}$ & average \\
\hline I am proud of my city's renewed downtown area & $8.1 \%$ & $27.4 \%$ & $44.5 \%$ & $20.0 \%$ & $\mathbf{2 . 7 6}$ \\
\hline The city offers many opportunities for youth to do sports & $8.0 \%$ & $28.1 \%$ & $45.4 \%$ & $18.5 \%$ & $\mathbf{2 . 7 4}$ \\
\hline $\begin{array}{l}\text { The standard of education in the city's high schools is } \\
\text { high. }\end{array}$ & $11.2 \%$ & $27.3 \%$ & $44.6 \%$ & $17.0 \%$ & $\mathbf{2 . 6 7}$ \\
\hline The city is held in high regard as it is a university town & $15.7 \%$ & $26.1 \%$ & $43.1 \%$ & $15.1 \%$ & $\mathbf{2 . 5 8}$ \\
\hline The city offers many opportunities for students to work. & $12.4 \%$ & $29.9 \%$ & $47.6 \%$ & $10.1 \%$ & $\mathbf{2 . 5 5}$ \\
\hline $\begin{array}{l}\text { There are many events organized in the city that target } \\
\text { younger audiences }\end{array}$ & $14.5 \%$ & $28.8 \%$ & $46.1 \%$ & $10.7 \%$ & $\mathbf{2 . 5 3}$ \\
\hline The city is constantly developing & $11.3 \%$ & $32.1 \%$ & $49.1 \%$ & $7.5 \%$ & $\mathbf{2 . 5 3}$ \\
\hline $\begin{array}{l}\text { Traffic in the city is suitable (including both public } \\
\text { transportation and travelling by car) }\end{array}$ & $15.1 \%$ & $28.9 \%$ & $46.3 \%$ & $9.7 \%$ & $\mathbf{2 . 5 1}$ \\
\hline $\begin{array}{l}\text { The city's leadership are performing their job on a high } \\
\text { level. }\end{array}$ & $11.1 \%$ & $33.3 \%$ & $50.7 \%$ & $4.9 \%$ & $\mathbf{2 . 4 9}$ \\
\hline The town is orderly and clean. & $13.9 \%$ & $30.4 \%$ & $48.1 \%$ & $7.6 \%$ & $\mathbf{2 . 4 9}$ \\
\hline Public safety is good in the city. & $13.7 \%$ & $31.5 \%$ & $48.5 \%$ & $6.3 \%$ & $\mathbf{2 . 4 8}$ \\
\hline The city's population enjoys a high standard of living. & $11.7 \%$ & $33.4 \%$ & $50.8 \%$ & $4.1 \%$ & $\mathbf{2 . 4 7}$ \\
\hline The city has a developed economy. & $13.2 \%$ & $33.5 \%$ & $50.9 \%$ & $2.4 \%$ & $\mathbf{2 . 4 3}$ \\
\hline Source: Author own results based on primary data & & & & \\
\hline
\end{tabular}


A predominant share (80\%) of respondents would welcome the creation of a youth center, $12 \%$ were unsure about it and $8 \%$ did not consider it beneficial or needful at all.

In order to provide useful information to the city, we asked questions in our survey about services, programmes and clubs the youth would welcome most in the youth center. Sports play a central role in the lives of generation $Z$ youth, which is reflected in the fact that the service most of them ( 817 respondents) want is a gym. This result is interesting, since there are several gyms available in the surveyed town that offer different opportunities to work out. However, the target audiences of those gyms aren't limited to members of generation Z, so it may well be that the popularity of potential youth center gyms among the youth is due to their preference of doing sports without the presence of older people. Next in the popularity ranking were pub classics, such as tabletop soccer and pool with 770 and 761 mentions, respectively. Different expectations regarding the preferred services of a potential youth center might be based on gender, so we surveyed this, too. Substantial (i.e., greater than $10 \%$ ) differences were observed regarding several services: pool, table tennis, tabletop soccer and sports grounds are more important to men, whereas women would prefer climbing walls, skateboard courses, theater studies or exhibition spaces.

In order to find out what things other than services are relevant in attracting the target generation to potential programmes and events, we surveyed respondents to obtain a better understanding in this regard as well. Entertainment came out on top unambiguously, with concerts, disco and karaoke parties mentioned most often. Besides these, organized excursions and hiking were proven to be of significant interest with 501 respondents mentioning them. Gender preferences have shown significant differences in these fields as well: theater and dance are more popular among women, however, events such as factory visits are mostly preferred by men. Youth centers are generally homes to self-organizing clubs, too. Since founding and creating such clubs might require support from the city, we surveyed which topics would be those of greatest interest to respondents. Movies and video games have proven to be the most popular among the youth, with photographing and cooking clubs also preferred by many. Gender-based differences in preference are observable, as men have shown more interest in computer games, card games, archery and board games clubs, with women preferring to be members of film, photographing, cooking and hiking clubs.

\section{Connections between staying and attachment}

Data were analyzed by cross-tabulation to confirm gender differences about staying in the town and personal attachment. The significance level in all examined cases was under 0.05 , so the 
correlation itself was proven. The strength of the correlation between the variables was different from each statement, between 0.104 and 0.214 . These data mean a weak correlation among the gender and the different statements about staying and attachment. The details are shown in the below table (2). $34 \%$ of women and $53.9 \%$ of men plan to continue their studies locally in order to obtain professional qualification. This can be explained by the fact that women tend to not aim for technological studies, which, to most, means skilled labor.

Table 2 Correlation between staying in town and sexes

\begin{tabular}{|l|l|l|l|l|}
\hline \multicolumn{4}{|l|}{} & 0.214 \\
\hline $\begin{array}{l}\text { I am planning to obtain professional } \\
\text { qualification in the city }\end{array}$ & $34.3 \%$ & $53.9 \%$ & 0.000 & 0.104 \\
\hline $\begin{array}{l}\text { I wish to continue my studies in a local higher } \\
\text { level education institution }\end{array}$ & $7.3 \%$ & $12.0 \%$ & 0.001 & 0.149 \\
\hline $\begin{array}{l}\text { There are several institutions/companies } \\
\text { where I can be employed once I have } \\
\text { completed my studies }\end{array}$ & $14.3 \%$ & $26.5 \%$ & 0.000 & 0.118 \\
\hline $\begin{array}{l}\text { I plan to stay here [in the city] once I have } \\
\text { completed my studies }\end{array}$ & $9.7 \%$ & $14.5 \%$ & 0.000 & \\
\hline
\end{tabular}

Source: Author own results based on primary data

The idea of picking a local higher education institution to study at received rather low averages: $7.3 \%$ of women and $12 \%$ of men plan to continue their studies at the local university. The reason behind such results may well be that the professional profile of the university is more attractive to men than it is to women, since the courses on offer are mainly aimed at those who are planning to obtain degrees in technological and engineering studies. As seen in Table $214.3 \%$ of women and $26.5 \%$ of men think that in case they decide to stay in town, they would easily find a local place where they could be employed at. The reason behind such difference is the aforementioned availability (or lack of) jobs that tend to attract more men than women.

The city's current economic profile focuses mostly on industry, which is a field that employs much less women than men, even in 2019. Finally, we also asked the respondents if they plan to remain in town for the future. While $14.5 \%$ of men said 'yes', the share of women answering identically is just $9.7 \%$. It is worth noting though, that both shares are low, which showcases the problem of small and medium-sized towns in Hungary: the migration of their youth away from home.

Other correlations were analyzed (like connection between town-evaluation and school-type, age categories), but those did not prove to be significant. 


\section{DISCUSSION}

Creating an environment which is attractive enough for young people to stay in their hometowns is a multifaceted challenge. Such an environment encompasses relevant ambitions in both a physical and an intellectual sense: a youth center may provide ample community spaces to members of generation $\mathrm{Z}$ or adolescents; however, the availability of spaces alone cannot offer the necessary configuration of services that must be tailor made for youths to achieve full effect. Once all components are in place, can we only consider a given town's youth policy compatible with the guidelines of positive youth development (PYD) theory and practice (Lerner, 2005) that enables young people to better engage in their community (Lerner et al., 2015; Roth \& Brooks-Gunn, 2016) and develop their talents locally (Benson et al., 2006; Roth \& BrooksGunn, 2003), thus empowering their sense of belonging (Heather et al., 2018; Peterson et al., 2011). Effective PYD programs are based on three core principles, such as providing possibilities to youth in taking part in certain community activities as well as letting them form long-lasting adult-youth relationships, while keeping an eye on sustaining proper, engaging and enduring skills which benefit them on the long run (Lerner, 2004; Wiecha et al., 2012).

According to literature (Garner and Zhao, 2000; Gareth et al., 2019) a way of keeping the youth in their hometowns is to create youth centers for them, where members of generation $\mathrm{Z}$ are able to spend time usefully and meaningfully. In order to understand if this is achievable in a middle-sized Hungarian town, we conducted a questionnaire-based survey. A predominant share $(80 \%)$ of respondents would welcome the creation of such a youth center, $12 \%$ were unsure about it and $8 \%$ did not consider it beneficial or needful at all. Most respondents (80\%) reacted positively to the idea of creating a youth center which would meet such needs, with only $8 \%$ opposing it and $12 \%$ of them being unsure.

Even though the creation and construction of a youth center requires plenty of resources from the city that is hosting it, operating it and creating suitable content for it can prove to be key factors in making it a success.

\section{CONCLUSION}

Rural-to-urban migration is a major concern for most of the small and medium-sized rural cities in Hungary as their youth tends to migrate to larger cities. In Hungary, the capital is considered the most attractive target city among youth migrating within the country. This is a common and persisting problem in all developed countries. In order to explore its causes, we deemed conducting an expansive survey among members of the concerned age groups necessary. 
Our main aim was to obtain a better picture regarding the livability of the city and we were also interested in understanding what the ambitions of the local youth were, once they finished their studies.

Creating an attractive environment for youth that encourages them to stay in their hometown is a multilayered challenge. According to the respondents, the construction and professional operation of a local youth center would strengthen their bonds to their town - they even formulated their own advices on what they would consider the most important in it if one were to be built. We believe that the creation of such a community space is a task that can be easily solved by local decision makers, so we recommend starting its development. In order to keep people in town, the availability of interesting and well-paid jobs is a must, since it is these jobs that create the desired standard of living. Achieving this is a top priority for most town leaders all over the world, and there is a huge competition to attract companies that offer such jobs, to settle in their respective towns. The city we have investigated, in its current status regarding size, general capacities, educational system and connections simply cannot be successful in this global competition. What is the way for it to go, then? The town needs a highly conscious development plan that aims to specialize in areas in which other towns don't. Doing so could turn it into a hub that is able to attract people from other regions, and, at the same time, keep its own residents in place, by offering them the prospect of an enduring higher standard of living. Specialization means the strengthening of capabilities that have been long available locally and still are, as well as finding a narrow field of expertise at which the town can excel, both in the market and in education alike. This area of expertise doesn't need to be a trendy one, in fact, the emphasis is on it being unique, as uniqueness is the characteristic that is most likely able to put a small or medium-sized town on the map and provide a desirable alternative for the increasingly more mobile young generation in global space.

\section{REFERENCES}

Benson, P. L., Scales, P. C., Hamilton, S. F., \& Sesma, A. Jr. (2006). Positive youth development: Theory, research, and applications. In Damon, W., \& Lerner, R. M. (series Eds.), \& Lerner, R. M. (Vol. Ed.): Handbook of child psychology. Vol. 1: Theoretical models of human development (6th ed., pp. 894-941). Hoboken, NJ: Wiley.

Brown, D. L., \& Schafft, K. A. (2002). Population deconcentration in Hungary during the postsocialist transformation. Journal of Rural Studies, 18(3), 233-244.

Caldwell, J. C. (1969). African rural-urban migration: the movement to Ghana's towns. Canberra, ACT: Australian National University Press.

Chittoor, P. (2018). Urbanization and deprived children education in India: emerging impediments. International Research Journal of Multidisciplinary Studies, 4(2).

Dövényi, Z., \& Kovács, Z. (2006). Urban development in Hungary after 1990. Spatial Planning and Urban Development in the New EU Member States. Aldershot, Ashgate, 163-179. 
Dziewonski, K. (1992). Changes in migrational patterns during the crisis and reform in Poland. Geographia Polonica, (59).

Eckert, E., Turner, E., \& Sallah, J. A. Y. (2019). Youth Rural-Urban Migration in Bungoma, Kenya: Implications for the Agricultural Workforce. RTI Press.

Jones, G. J., Edwards, M. B., Bocarro, J. N., Svensson, P. G., \& Misener, K. (2019). A community capacity building approach to sport-based youth development. Sport Management Review, 23(4), 563-575.

Garner, R. \& Zhao, Y. (2000). Afterschool centers in four rural communities in Michigan. Computers in Human Behavior, 16(3), 301-311.

Gáti, M., Malota, E. (2017). The relationship between international students' satisfaction with general and educational facilities and their repeated choice concerning the higher educational destination. EDULEARN17 - 9th International Conference on Education and New Learning Technologies. Barcelona, Spain.

Global Migration and Youth Report (2016)

http://www.ilo.org/global/research/globalreports/youth/2016/lang--en/index.htm _Accessed: 12. September, 2019

Global Migration Group: Migration and Youth (2014)

http://www.globalmigrationgroup.org/sites/default/files/0._Cover_and_Acknowledgements_\%2 81\%29.pdf_Accessed: 16. September, 2019

Greenwood, M. J. (2001). Internal Migration (Further Types): Industrialized Countries. In International Encyclopedia of the Social \& Behavioral Sciences, pp. 7737-7741.

Günther, J. (2000). Regional unemployment differentials and internal migration in Hungary. SEER-South-East Europe Review for Labour and Social Affairs, 3(1), 135-145.

Gyulavári, T. (2013). Lojalitásprogramok menedzselése. [Loyalty Programme management] Vezetéstudomány, 43(5), 16-26.

Ramey, H. L., Lawford, H. L. Rose-Krasnor, L., Freeman J., \& Lanctot J. (2018). Engaging diverse Canadian youth in youth development programs: Program quality and community engagement. Children and Youth Services Review, 94, 20-26.

Horváth, T. M. (2016). From municipalisation to centralism: Changes to local public service delivery in Hungary. In Wollmann H., Koprić I., Marcou G. (eds): Public and Social Services in Europe. Governance and Public Management. pp. 185-199. Palgrave Macmillan, London.

Internal migration in Hungary 1990 to 2018 https://www.ksh.hu/docs/eng/xstadat/xstadat_annual/i_wnv001.html Accessed: 16. January, 2020

International Union for the Scientific Study of Population (1982). Multilingual Demographic Dictionary. Dolhain, Belgium: Ordina Editions

https://ec.europa.eu/knowledge4policy/organisation/iussp-international-union-scientificstudy-population_en 2019.09.12 Accessed: 16. September, 2019

Kok, H. (1999). Migration from the city to the countryside in Hungary and Poland. GeoJournal, 49(1), 53-62.

Kovács, K. (2012). Rescuing a small village school in the context of rural change in Hungary. Journal of Rural Studies, 28(2), 108-117.

KSH, 2017 (Hungarian Central statistical office, 2017 report http://www.ksh.hu/docs/hun/xftp/idoszaki/mo/hungary2017.pdf Accessed: 17 October 2020.

Kummitha, H. R. (2020). Eco-Entrepreneurs Organizational Attitude Towards Sustainable Community Ecotourism Development. The Central European Journal of Regional Development and Tourism, 12(1), pp. 85-101. 
Lerner, R. M. (2004). Liberty: Thriving and civic engagement among American youth. Thousand Oaks, CA: Sage.

Lerner, R. M. (2005). Promoting positive youth development: Theoretical and empirical bases. White paper prepared for: Workshop on the Science of Adolescent Health and Development. Washington DC: National Research Council.

Lerner, R. M., Lerner, J. V., Bowers, E. P., \& Geldhof, G. J. (2015). Positive youth development: A relational developmental systems model. In W. F. Overton \& P. C. Molenaar (Eds.) and R. M. Lerner (Editor-in-Chief), Theory and method. Vol. 1: The handbook of child psychology and developmental science (7th ed., pp. 607-651). Hoboken, NJ: Wiley.

Malota, E. (2012) Global cultures? Consequences of globalization on cultural differences, a commentary approach. International Journal of Business Insights and Transformation, 5(3), pp. 94-100.

Miguel, E., \& Hamory, J. (2009). Individual ability and selection into migration in Kenya. MPRA Papers 19228, University Library of Munich, Germany.

Okhankhuele, O. T., \& Opafunso, O. Z. (2013). Causes and consequences of rural-urban migration Nigeria: A case study of Ogun Waterside local Government area of Ogun State, Nigeria. British Journal of Arts and Social Sciences, 16(1), 197-206.

Ország, G., \& Szobonya, R. (2013). Migration Actualities of the Students of Budapest Business School Graduated between 2007 and 2010 Placing Emphasis on the Differences in Development of the Country's Regions. Acta Carolus Robertus, 3(1), 214-222.

Peterson, N. A., Peterson, C. H., Agre, L., Christens, B. D., \& Morton, C. M. (2011). Measuring youth empowerment: Validation of a sociopolitical control scale for youth in an urban community context. Journal of Community Psychology, 39(5), 592-605.

Roth, J. L., \& Brooks-Gunn, J. (2003). What exactly is a youth development program? Answers from research and practice. Applied Developmental Science, 7(2), 94-111.

Roth, J. L., \& Brooks-Gunn, J. (2016). Evaluating youth development programs: Progress and promise. Applied Developmental Science, 20(3), 188-202.

Ramachandran, V. (2006). Urban Schooling: Mired in Apathy and Prejudice. Economic and Political Weekly, 41(5), pp. 383-384.

Sajtos, L., \& Mitev, A. (2007). SPSS Kutatási és adatelemzési kézikönyv. Alinea Kiadó, Budapest

Szőke, V., \& Kovács, L. (2016). Klassische Modelle der Raumstruktur und der räumlichen Beziehungen am Beispiel des Bildungswesens im westungarischen Komitat Vas. [Classic models of spatial structures and connections as exemplified in the educational system of Vas county, Western Transdanubia] A NYME Savaria Egyetemi Központ Tudományos Közleményei 21.; Természettudományok 16. 81-89.

Sawyer, M. G., Arney, F. M., Baghurst, P. A., Clark, J. J., Graetz, B. W., Kosky, R. J....Whaites, L.C. (2001). The mental health of young people in Australia: key findings from the child and adolescent component of the national survey of mental health and well-being. Australian and New Zealand Journal of Psychiatry, 35(6), 806-814.

The International Organization for Migration, http://www.iom.hu/migration-issues-hungary Accessed: 10. September, 2019

Wiecha, J. L., Hall, G., Gannett, E., \& Roth, B. (2012). Development of healthy eating and physical activity quality standards for out-of-school time programs. Childhood Obesity, $8(6), 572-576$. 